\title{
Pengujian dan Model Penerimaan Aplikasi Web Mapping System Lahan Pertanian
}

\author{
http://dx.doi.org/10.28932/jutisi.v7i1.3336 \\ Riwayat Artikel \\ Received: 25 Januari 2021 | Final Revision: 9 Maret 2021 | Accepted: 16 Maret 2021
}

\author{
Delfia Balisa ${ }^{\bigotimes \# 1}$, Rosa Delima ${ }^{\# 2}$, Antonius Rachmat Chrismanto ${ }^{\# 3}$, Halim Budi Santoso ${ }^{\# 4}$ \\ \#Prodi Informatika, Fakultas Teknologi Informasi \\ Universitas Kristen Duta Wacana, Yogyakarta \\ ${ }^{1}$ delfia.balisa@ti.ukdw.ac.id \\ ${ }^{2}$ rosadelimalstaff.ukdw.ac.id \\ 3antoneti.ukdw.ac.id \\ ${ }^{4}$ hbudilastaff.ukdw.ac.id
}

\begin{abstract}
The entry of technology in agriculture also has a big influence in supporting farmers for making their work easier. Many agricultural systems are formed that can encourage the success of farming productivity, such as in a system for collecting farmer data and farming activities, a land management system, a land preparation system, and a system that provides information as learning for farmers and farmer groups. In this research, the usability test and acceptance test of the web application mapping system for agricultural land will be carried out to see the level of usability test and the level of acceptance of the system in case of farmers group. The Technology Acceptance Model (TAM) method is used, and it is used an eye tracker tool in testing method and the Partial Least Square (PLS) software to process the data. The results of this study indicate the level of usability of the combining metrics task success is $93 \%$, the time on task is $43 \%$, the error rate is $60 \%$, and the efficiency is $70 \%$. For the results of the acceptance test, it was obtained that two of the five hypotheses had a significant influence, namely the perceived ease of perception on the perceived usefulness and the perceived attitude of use towards behavioral interest. From these results it can be concluded that the perceived ease of use of the web mapping system application can increase the user's perception of the usefulness of the web mapping system application to increase the effectiveness of their work. In addition, the attitude of users who are motivated in using the system can also increase their intention to routinely use the system in the future continuously to support their activities in agriculture.
\end{abstract}

Keywords- Eye Tracking; Partial Least Square; Technology Acceptance Model; Usability Testing; Web Mapping System;

\section{Pendahuluan}

Kemajuan teknologi informasi menyebabkan perubahan yang cukup besar dalam berbagai bidang, begitu juga pada bidang pertanian. Dengan masuknya teknologi informasi di bidang tersebut dapat mendukung keberhasilan produktivitas usaha tani yang mendorong terbentuknya beberapa sistem informasi pada bidang pertanian. Sistem informasi yang dimaksud menyediakan berbagai informasi yang terkait seperti sistem penjualan dan pembelian hasil panen, sistem untuk pendataan petani dan aktivitas pertanian, sistem pengolahan lahan, persiapan lahan, hingga sistem yang menyediakan informasi sebagai pembelajaran bagi petani maupun kelompok tani.

Salah satu sistem yang telah dikembangkan dalam bidang pertanian adalah sistem pemetaan (mapping) untuk lahan pertanian. Sistem ini dibuat dengan tujuan untuk menampilkan informasi yang dapat membantu petani dalam memudahkan bagian pengurusan, pencatatan dan juga membantu untuk menampilkan data lahan pertanian [1].

Dalam mencapai keberhasilan pengimplementasiannya, sistem web mapping pada lahan pertanian, memerlukan informasi untuk mengetahui tingkat kebergunaan dan tingkat penerimaan sistem oleh user. Dalam menganalisis kebergunaan sistem web mapping dengan tujuan untuk mengetahui seberapa besar tingkat usabilitas sistem tersebut diukur menggunakan metode usability testing berdasarkan keempat aspek yaitu time-on-task, task success, error dan efficiency dengan bantuan alat eye tracking [2]. Analisis hasil pengujian usability sistem telah dibahas pada artikel publikasi yang berbeda [3]. Untuk menganalisis tentang penerimaan dilakukan untuk mengetahui seberapa besar tingkat penerimaan teknologi sistem tersebut menggunakan software SmartPLS ${ }^{l}$.

${ }^{1}$ https://www.smartpls.com/ 


\section{LANDASAN TEORI}

\section{A. Web Mapping System}

Web mapping system merupakan peta digital yang ditampilkan melalui sebuah sistem [4]. Web mapping merupakan gabungan sebuah alat yang canggih dari sistem informasi grafis yang dapat menganalisis keruangan yang dipadukan dengan internet sebagai media penyampaian informasi yang efektif. Namun web mapping lebih difokuskan dalam penyampaian informasinya, bukan sebagai alat bantu analisis secara kompleks. Dengan adanya web apping system peningkatan penggunaan informasi berbasis peta dapat dikembangkan menjadi pemetaan yang dinamis dan dapat diakses kapanpun [5].

Dengan adanya web mapping system dalam bidang pertanian, yang dapat menampilkan informasi kepemilikan tanah, dapat membantu para petani dalam mengorganisir kegiatan untuk meningkatkan produksi pertanian. Dalam menjalankan fungsinya, informasi web mapping system tersebut harus memuat beberapa fitur penting seperti membuat, membaca, memperbarui dan menghapus (CRUD) data lahan, titik persebaran lahan, serta informasi lahan rdasarkan petani maupun wilayahnya [6].

\section{B. Teknologi Eye Tracking}

Eye tracking merupakan suatu proses mengukur gerakan mata atau pandangan mata yang akan dihantarkan ke otak dengan menggunakan suatu alat yang disebut eye tracker. Eye tracker dapat mengukur posisi mata dan pergerakan mata ketika berhenti untuk menatap suatu objek [7].

Dengan adanya teknologi eye tracking, kesulitan yang dihadapi oleh pengguna dapat diamati melalui pergerakan matanya sehingga penelitian ini mengetahui elemen mana pada sebuah tampilan yang dapat mengalihkan perhatian pengguna [8].

\section{Technology Acceptance Model (TAM)}

Technology Acceptance Model digunakan untuk menganalisis faktor faktor yang mempengaruhi dapat diterimanya suatu sistem informasi atau teknologi informasi yang dikembangkan pertama kali oleh Fred Davis pada tahun 1989. Dengan tujuan untuk menjelaskan penerimaan pengguna terhadap sebuat sistem informasi, TAM menyediakan suatu basis teori yang dapat menjelaskan hubungan sebab akibat antara yang mengacu pada kepercayaan, sikap, minat dan hubungan perilaku pengguna [9]. Variabel TAM yang dikembangkan oleh Fred Davis dapat dilihat pada Gambar 1.

Teori TAM memiliki ciri khusus yaitu sederhana tetapi bisa memprediksi penerimaan maupun penggunaan teknologi. Dalam teori ini, terdapat variabel eksternal yang disesuaikan dengan objek maupun topik penelitian. Variabel eksternal akan dianalisis dengan dua persepsi, yaitu kemudahan penggunaan (perceived easy of use) dan kebermanfaatan (perceived usefulness). Dari persepsi kemudahan diprediksi akan mempengaruhi prediksi kebermanfaatan pula. Lalu dari persepsi kemudahan dan kebermanfaatan akan mempengaruhi sikap (perceived attitude to towards using) terhadap penggunaan sebuah sistem yang selanjutnya akan berpengaruh pada intensitas penggunaan (perceived behavioral intention to use). Setelah itu maka akan mempengaruhi penggunaan sistem secara aktual (actual system use) [9].

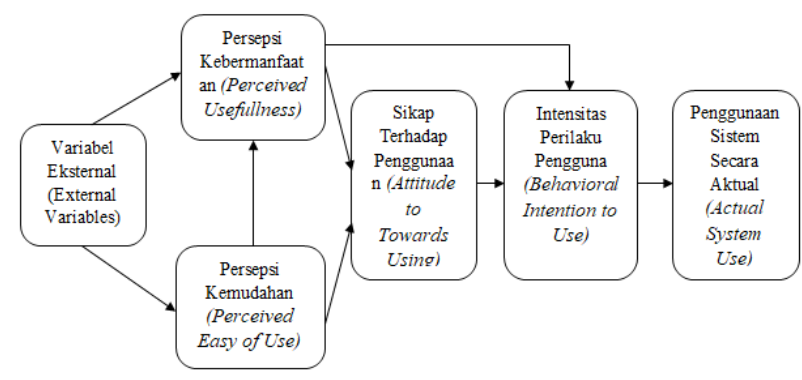

Gambar 1. Technology Acceptance Model

\section{Sistem Web Mapping Lahan Pertanian}

Sistem web mapping lahan pertanian merupakan sistem pencatatan lahan yang digunakan untuk melakukan pencatatan status lahan pertanian yang meliputi sarana dan prasarana yang dapat digunakan petani untuk mengolah lahan tersebut [10]. Sistem ini dapat menampilkan data pada peta di dashboard yang sudah tercatat pada basis data yang dilengkapi dengan berbagai fitur. Fitur tersebut memiliki fungsi untuk melakukan pencatatan dan perubahan data, seperti kepemilikan lahan, penanaman lahan, titik detail lahan dan foto lahan. Pada dashboard sistem dibagi menjadi tiga bagian yaitu filter data, peta dan data statistik lahan. Selain itu terdapat peta yang dapat ditampilkan pada sistem, yaitu peta persebaran titik lahan, peta persebaran lahan, dan peta gabungan lahan [11]. Beberapa fitur yang ada dalam web mapping system lahan pertanian adalah halaman login, halaman utama admin, peta persebaran lahan, peta gabungan lahan, daftar petani, data lahan petani, tambah lahan pertanian, tambah kepemilikan lahan, dan tambah data penanaman lahan. Berikut ini adalah contoh tampilan sistem yang dapat dilihat pada Gambar 2, 3 dan 4.

1. Halaman Login, digunakan oleh admin untuk masuk ke dalam sistem. Tampilan login seperti pada Gambar 2 dibawah. 


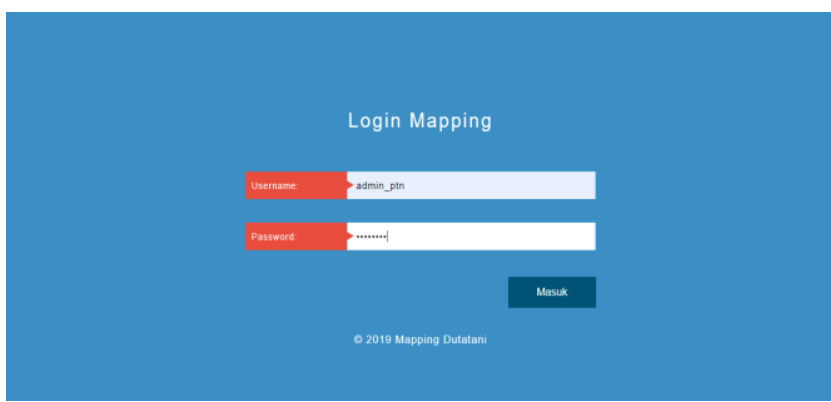

Gambar 2. Halaman Login

2. Halaman utama admin adalah tampilan awal pada sistem web mapping lahan pertanian. Tampilan halaman utama admin seperti Gambar 3.

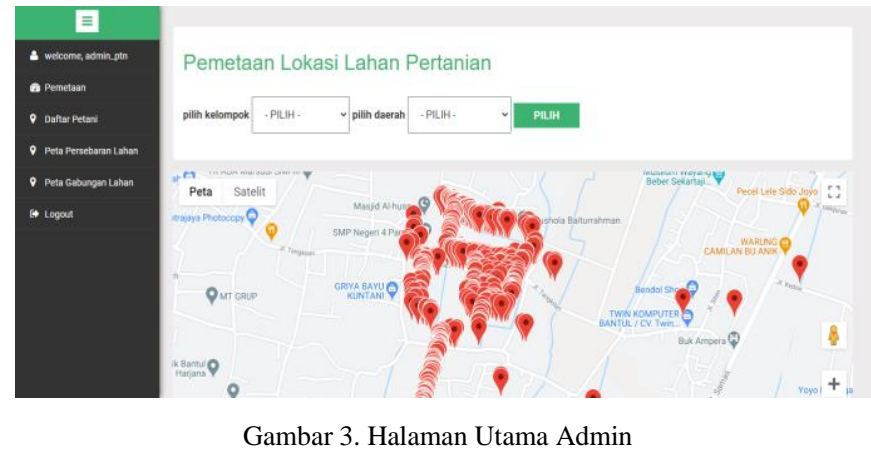

3. Halaman tambah lahan, digunakan oleh admin untuk menambahkan lahan petani. Halaman tambah lahan ditampilkan seperti Gambar 4.

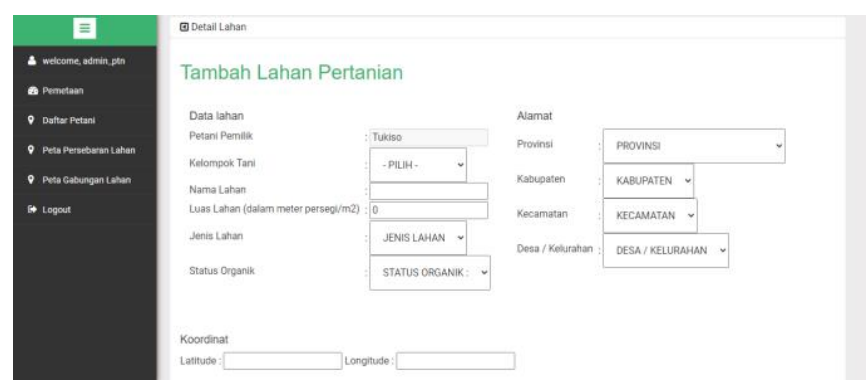

Gambar 4. Halaman Tambah Lahan

\section{METODOLOGI PENELITIAN}

\section{A. Metodelogi penelitian}

Dalam melakukan penelitian ini, dibutuhkan tahapantahapan agar penelitian berjalan sesuai yang direncanakan. Tahapan-tahapan dalam penelitian ditunjukkan pada Gambar 5. Pada Gambar 5 ditampilkan alur penelitian dimana akan dilakukan studi pendahuluan, pemilihan responden, persiapan uji usabilitas, pengujian usabilitas, analisis hasil uji usabilitas, perbaikan desain antarmuka, persiapan uji penerimaan, uji validitas dan uji reliabilitas kuesioner, olah

\footnotetext{
${ }^{2}$ https://gaming.tobii.com/product/eye-tracker-5/
}

dan danalisis data, dan kesimpulan serta saran dari pengujian penerimaan.

\section{B. Studi Pendahuluan}

Dalam Studi pendahuluan merupakan tahapan awal dalam penelitian ini. Studi pendahuluan dilakukan untuk mendapatkan informasi yang berkaitan dengan penelitian, yaitu web mapping system dan metode-metode yang digunakan. Informasi yang didapatkan bisa melalui berbagai sumber seperti buku, artikel-artikel maupun jurnal. Dari beberapa referensi yang didapatkan, metode Technology Acceptance Model (TAM) dipilih untuk melakukan pengujian penerimaan, sedangkan untuk pengujian usabilitas digunakan metode Combining Metrics. Sebelum dilakukan pengujian usabilitas dan penerimaan sistem terhadap responden, dipelajari sistem web mapping lahan pertanian terlebih dahulu. Pada penelitian ini juga menggunakan eye tracker Tobii Eye Tracker $4 \mathrm{C}^{2}$. Penggunaan eye tracker bersamaan pada saat responden menggunakan sistem web mapping namun sebelumnya akan dikalibrasikan terlebih dahulu dengan mata responden. Arsitektur sistem web mapping lahan pertanian ditampilkan seperti Gambar 6 . 


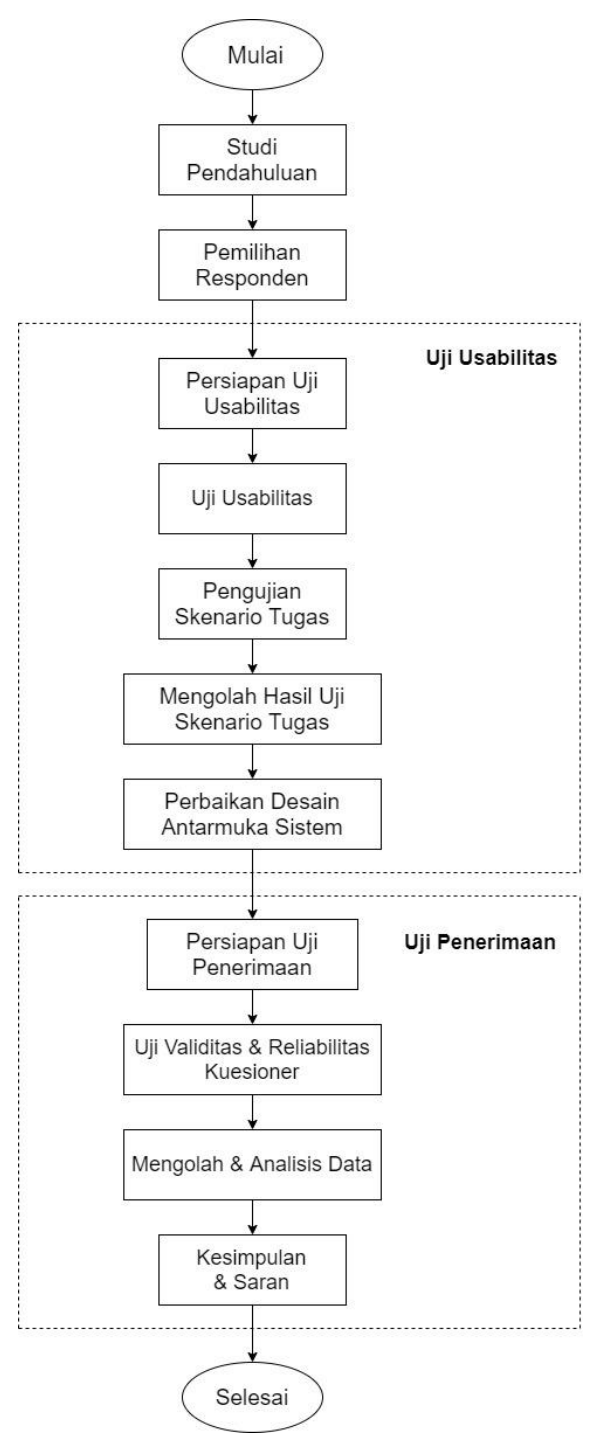

Gambar 5. Alur Penelitian

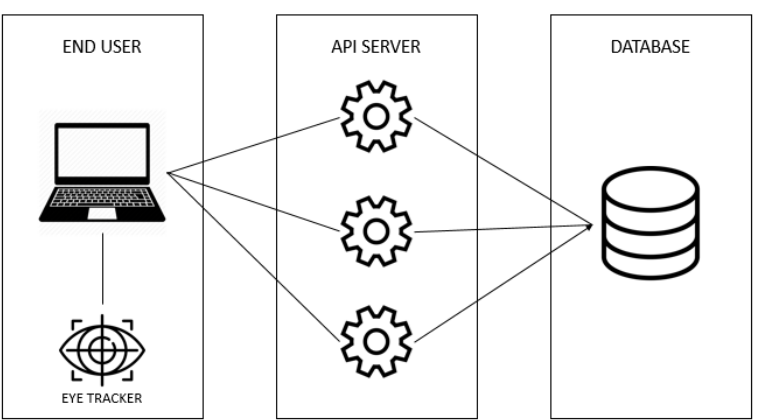

Gambar 6. Arsitektur Web Mapping System

\section{Pemilihan Responden}

Dalam penelitian ini, responden untuk uji usabilitas akan disamakan dengan responden uji penerimaan. Responden akan dipilih sebanyak 20 responden yang terdiri dari petani dan pengurus kelompok tani yang berdomisili di Daerah Istimewa Yogyakarta (DIY) yang dapat mewakili seluruh kriteria responden. Kriteria responden adalah:

- Usia minimal 20 tahun

- Memiliki lahan pertanian

\section{Pemberian Tugas}

Dokumen yang diberikan berisi tentang tugas yang akan dikerjakan oleh responden. Setelah itu responden akan diberikan waktu untuk memahami skenario tugas tersebut. Sebelum pengujian dimulai, akan diaktifkan aplikasi $\mathrm{OBS}^{3}$ untuk merekam layar, mousotron untuk mencatat jumlah klik, dan Tobii Eye Tracker 4C untuk merekam pergerakan mata. Setelah itu pengujian dilakukan dan responden mengerjakan semua task, berdasarkan skenario tugas yang disiapkan. Batas waktu kegagalan responden dalam menyelesaikan sebuah tugas akan dihitung dengan cara mencatat waktu penyelesaian tugas, lalu waktu tersebut dikalikan 2 (dua). Kemudian data yang didapatkan dari hasil pengujian akan dijadikan sebagai bahan analisis data keberhasilan menggunakan metriks keberhasilan.

\section{E. Perhitungan Data Uji}

Setelah didapatkan data hasil uji maka langkah selanjutnya adalah mengolah data yang akan dihitung menggunakan Combining Metrics Based on Percentages. Teknik perhitungan Combining Metrics Based on Percentages adalah penggabungan nilai pada skala yang berbeda untuk mengkonversi masing-masing skor ke dalam persentase kemudian mengambil nilai rata-rata [12].

\section{F. Persiapan Uji Penerimaan}

Uji penerimaan dilakukan dengan menggunakan metode Technology Acceptance Model. Untuk melakukan pengujian penerimaan aplikasi web mapping system lahan pertanian, akan dilakukan persiapan-persiapan sebagai berikut:

1) Merumuskan Hipotesis: membuat hipotesis sebagai jawaban sementara dari pertanyaan-pertanyaan yang diajukan. Dimana pertanyaan tersebut memuat hubungan antar variabel TAM yang akan teliti. Hipotesis dalam penelitian ini adalah:

- H1: Terdapat pengaruh positif antara persepsi kemudahan (perceived ease of use) terhadap persepsi kegunaan (perceived usefulness).

- H2: Terdapat pengaruh positif antara persepsi kemudahan (perceived ease of use) terhadap sikap Penggunaan (attitude toward use).

- H3: Terdapat pengaruh positif antara persepsi kegunaan (perceived usefulness) terhadap sikap penggunaan (attitude toward use).

\footnotetext{
${ }^{3}$ https://obsproject.com/
} 
- H4: Terdapat pengaruh positif antara persepsi kegunaan (perceived usefulness) terhadap minat perilaku penggunaan (behavioral intention to use).

- H5: Terdapat pengaruh positif antara sikap penggunaan (attitude toward use) terhadap minat perilaku penggunaan (behavioral intention to use).

2) Penentuan Sampel dan Populasi: Dalam penelitian web mapping system lahan pertanian ini, populasi yang akan digunakan adalah semua petani yang tersebar di sekitar DIY. Alasan pengambilan populasi di daerah DIY adalah agar memudahkan pengumpulan data. Sedangkan dalam penentuan sampel digunakan purposive sampling. Teknik purposive sampling merupakan teknik pengambilan sampel dengan pertimbangan tertentu. Sampel yang akan dipilih berkaitan dengan kriteria-kriteria yang telah disusun yang disesuaikan dengan tujuan atau permasalahan penelitian.

3) Penentuan Variabel Penelitian: Penelitian ini menggunakan metode Technology Acceptance Model dalam menganalisis penerimaan aplikasi web mapping system. Dengan menggunakan lima variabel bebas yaitu persepsi kemudahan (Perceived ease of use) sebagai variabel bebas pertama (PEU), persepsi kegunaan (Perceived Usefulness) sebagai variabel bebas kedua (PU), sikap penggunaan (Attitude Toward Use) sebagai variabel bebas ketiga (ATU), dan minat perilaku penggunaan (Behavioral Intention to Use) sebagai variabel bebas keempat (BITU).

4) Pengumpulan Data: Pengumpulan data dilakukan dengan cara pengujian sistem. Setelah itu dilanjutkan pemberian kuesioner yang berisi beberapa pertanyaan yang memuat indikator-indikator variabel TAM kepada responden. Lalu setelah responden mengisi kuesioner, kemudian kuesioner tersebut dikumpulkan untuk dilakukan uji validitas dan reliabilitas kuesioner. Kuesioner pada penelitian ini menggunakan skala likert mulai dari 1 untuk "sangat setuju" sampai 5 untuk "sangat tidak setuju" [13].

\section{G. Perancangan Model PLS}

1) Perancangan Inner Model: Inner model atau biasa disebut model struktural merupakan model yang menghubungkan antar variabel laten. Variabel laten pada penelitian ini didasarkan pada hipotesis yang sudah dirancang seperti Gambar 7.

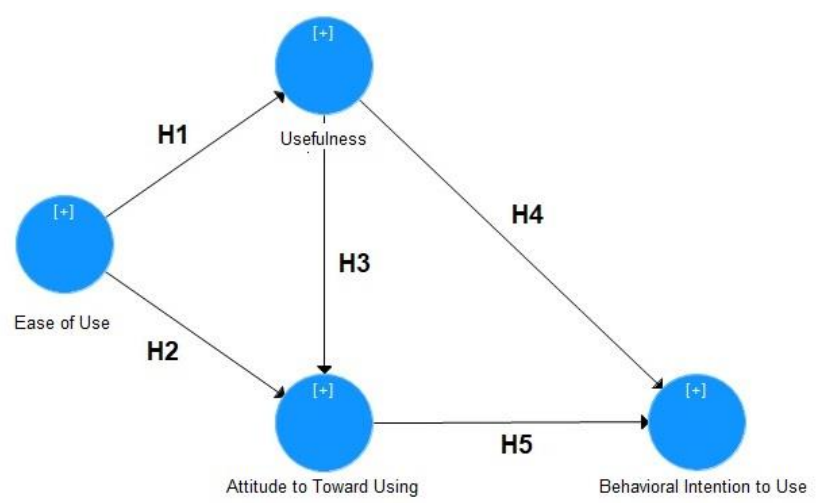

Gambar 7. Perancangan Inner Model

2) Perancangan Outer Model: Inner Outer model atau model pengukuran merupakan model yang menggambarkan hubungan antara variabel laten dengan masing - masing indikator seperti pada Gambar 8. Berikut adalah indikator dari masing - masing variabel yang dapat dilihat pada Tabel I.

TABEL I

INDIKATOR VARIABEL INNER MODEL

\begin{tabular}{|c|c|}
\hline Variabel & Indikator \\
\hline Kegunaan (PU) & $\begin{array}{ll}\text { - } & \text { Meningkatkan kinerja } \\
\text { - } & \text { Meningkatkan kualitas hasil } \\
& \text { pekerjaan } \\
\text { - } & \text { Produktivitas } \\
\text { - } & \text { Efektifitas }\end{array}$ \\
\hline Kemudahan (PEU) & $\begin{array}{ll}\text { - } & \text { Meningkatkan kinerja } \\
\text { - } & \text { Meningkatkan kualitas hasil } \\
& \text { pekerjaan }\end{array}$ \\
\hline $\begin{array}{l}\text { Sikap Penggunaan } \\
\text { (ATU) }\end{array}$ & $\begin{array}{ll}\text { - } & \text { Rasa menerima } \\
\text { - } & \text { Rasa menolak } \\
\text { - } & \text { Perasaan (afektif) } \\
\end{array}$ \\
\hline $\begin{array}{l}\text { Minat Perilaku } \\
\text { Penggunaan (BITU) }\end{array}$ & $\begin{array}{ll}\text { - } & \text { Rencana untuk tetap } \\
\text { menggunakan sistem di masa } \\
\text { mendatang } \\
\text { - } & \text { Minat mengajak orang lain } \\
\text { untuk menggunakan sistem } \\
\text { - } \\
\begin{array}{l}\text { Minat untuk memberikan saran } \\
\text { perbaikan }\end{array} \\
\end{array}$ \\
\hline
\end{tabular}

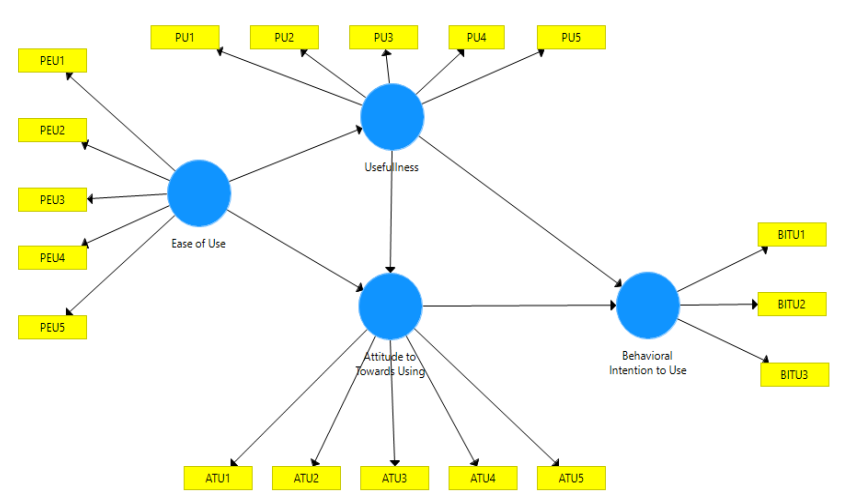

Gambar 8. Perancangan Outer Model 


\section{H. Evaluasi Model PLS}

1) Evaluasi Outer Model: Model pengukuran dalam penelitian ini akan dievaluasi dengan menggunakan Convergent Validity, Discriminant Validity dan Composite Reliability [14].

- Convergen validity, dalam partial least square nilai convergen validity diperoleh dari nilai loading factor. Nilai loading factor merupakan nilai korelasi antara variabel laten dan indikator variabelnya. Nilai loading factor dianggap tinggi apabila nilai yang dihasilkan adalah diatas 0,7 .

$$
A V E=\frac{\sum \lambda i^{2}}{\sum \lambda i^{2}+\sum i \operatorname{var}(\epsilon i)}
$$

- Discriminant validity, nilai dicriminant validity dapat dilihat dari nilai AVE (average variance extracted) yang dihasilkan dari korelasi antar variabel laten. Nilai AVE yang melebihi 0,5 dapat dianggap sudah cukup baik.

- Composite reliability, uji reliabilitas dapat diperoleh dengan melihat nilai-nilai composite reliability. Apabila nilai composite reliability diatas 0,7 maka dapat dikatakan bahwa indikator tersebut sudah reliabel.

$$
\rho c=\frac{\left(\sum \lambda i\right)^{2}}{\left(\sum \lambda i\right)^{2}+\sum i \operatorname{var}(\epsilon i)}
$$

2) Evaluasi Inner Model: Evaluasi model struktural dilakukan untuk melihat hubungan antar variabel yang diteliti dengan mengamati nilai koefisien determinasi $\left(\mathrm{R}^{2}\right)$ dan nilai koefisien jalur serta signifikansinya [14].

- Koefisien Determinasi $\left(\mathrm{R}^{2}\right)$. Penggunaan koefisien determinasi dalam partial least square digunakan untuk melihat efek gabungan dari variabel eksogen dan variabel endogen.

- Nilai Koefisien Jalur. Nilai koefisien jalur yang didapat dibandingkan dengan nilai $\mathrm{T}$ lalu digunakan untuk menentukan signifikansi antar variabel dengan hipotesis yang diajukan.

\section{Pengolahan dan Analisis Data}

Setelah dilakukan uji validitas dan uji reliabilitas, maka selanjutnya adalah mencari nilai koefisien korelasi antar variabel berdasarkan hipotesis yang sudah dibuat. Nilai koefisien korelasi yang didapatkan nanti akan dibandingkan dengan $\mathrm{t}$ tabel. Dimana $\mathrm{t}$ tabel merupakan nilai tabel yang menjadi acuan apakah hipotesis dapat diterima atau ditolak. Apabila koefisien korelasi lebih besar dari nilai t tabel, maka dapat dikatakan bahwa terdapat hubungan yang signifikan (hipotesis diterima). Sebaliknya, apabila koefisien korelasi lebih kecil dari nilai $\mathrm{r}$ tabel, maka hipotesis ditolak karena tidak ada hubungan yang signifikan.

\section{J. Kesimpulan}

Berdasarkan uraian-uraian di atas, setelah dilakukan pengujian hipotesis akan didapatkan kesimpulan tentang konstruk atau variabel mana yang saling memiliki pengaruh terhadap penerimaan aplikasi web mapping system. Kemudian dari situ dapat diketahui juga variabel mana yang tidak memiliki pengaruh terhadap aplikasi sistem web mapping sehingga dapat diberikan saran untuk perbaikan antarmuka sistem yang lebih baik.

\section{HASIL DAN ANALISIS}

\section{A. Responden Penelitian}

Data yang diperoleh dari proses pengujian adalah sebanyak 20 responden yang berstatus sebagai petani yang tergabung dalam kelompok Tani Harjo dan Tani Rahayu. Pengujian sistem dilakukan pada tanggal 22 Juli 2020 hingga 24 Juli 2020 di desa Gilangharjo Bantul.

\section{B. Hasil Perbaikan}

Pengujian dilakukan berdasarkan 13 skenario tugas dan tersebut dianalisis menggunakan metode usability testing [3] Berdasarkan hasil analisis tersebut, disampaikan beberapa saran perbaikan yang dapat digunakan untuk perbaikan sistem yaitu memperbesar tulisan dan icon pada button back pada sistem agar terlihat lebih jelas dan menggunakan bahasa indonesia pada semua perintah di menu seperti pada Gambar 9 hingga Gambar 12.

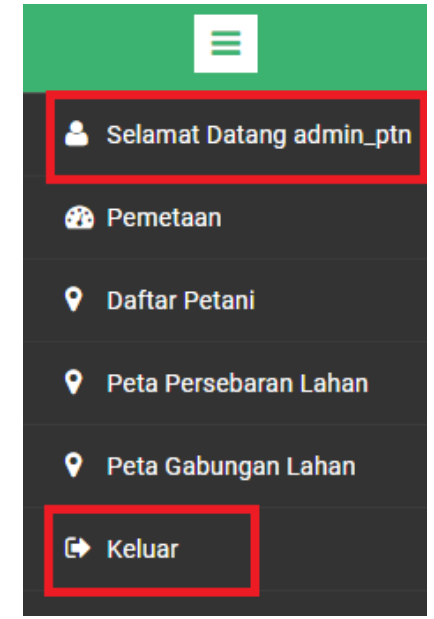

Gambar 9. Hasil perbaikan halaman menu 

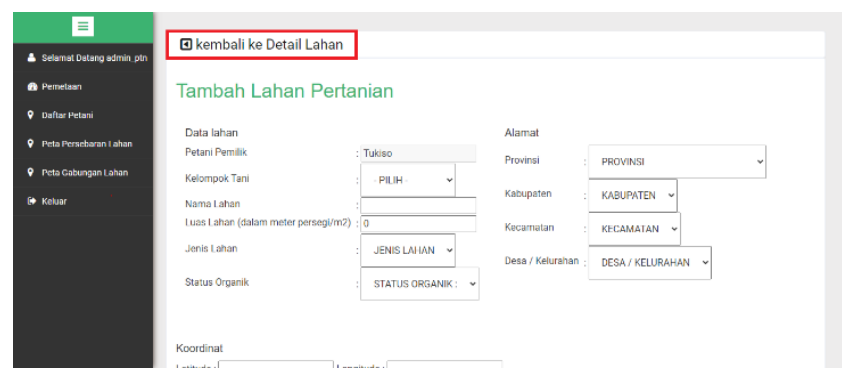

Gambar 10. Halaman Tambah Lahan
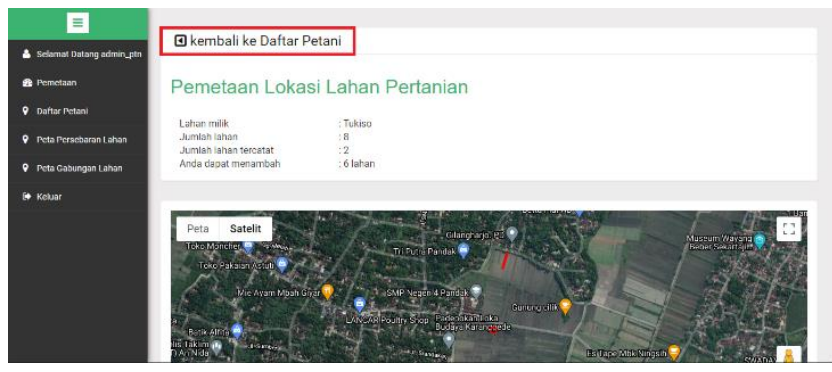

Gambar 11. Halaman Petani
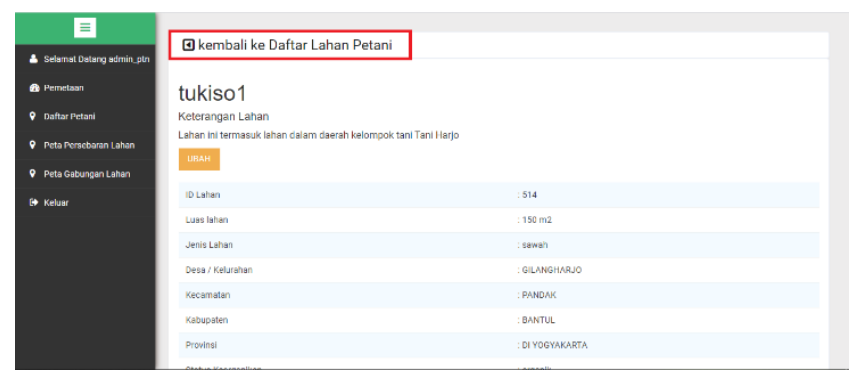

Gambar 12. Halaman Detail Petani

\section{Hasil Visualisasi Heatmap}

Heatmap digunakan untuk mengetahui jumlah fiksasi yang dilakukan oleh semua responden pada halaman tertentu [15]. Dari hasil pengujian yang dilakukan, diperoleh hasil visualisasi heatmap dimana pada heatmap tersebut terdapat beberapa warna. Warna pada heatmap menunjukkan banyaknya fiksasi yang terjadi. Semakin merah warna pada area tertentu maka semakin banyak fiksasi pada area tersebut. Terdapat 13 hasil visualisasi heatmap dibawah ini berdasarkan task skenario yang diujikan [3]. Hasil visualisasi heatmap bisa dilihat pada Gambar 13 sampai Gambar 25.

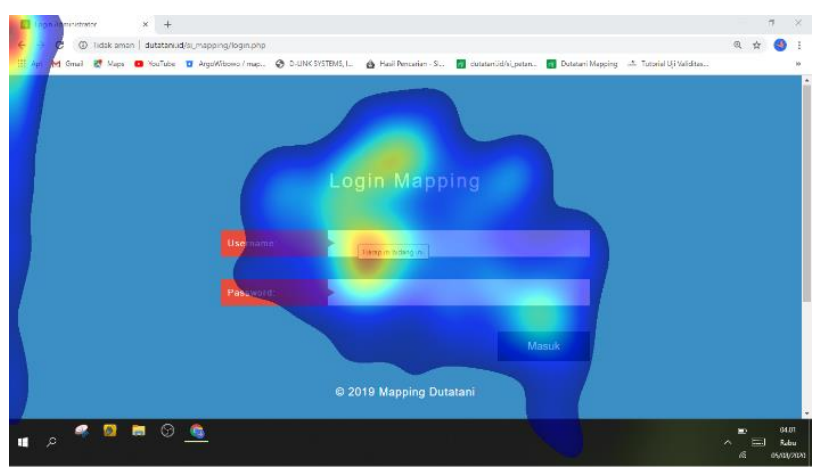

Gambar 13. Heatmap halaman login

Gambar 13 diatas, menujukkan hasil heatmap pada task 1 [3]. Responden diminta untuk login kedalam sistem dan menginputkan username dan password. Berdasarkan hasil heatmap diatas, disimpulkan bahwa rata-rata responden mengarahkan mata mereka ke arah tengah halaman yang ditandai dengan warna kuning.

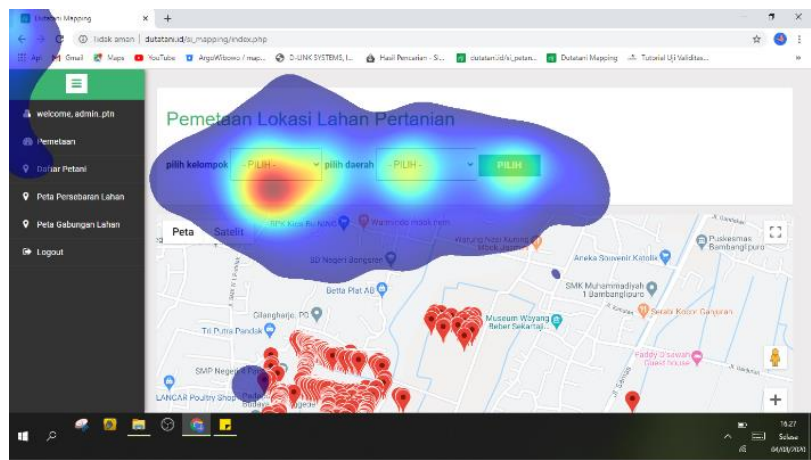

Gambar 14. Heatmap halaman pemetaan lahan

Heatmap pada Gambar 14, menujukkan hasil heatmap pada task 2 [3]. Responden lebih banyak melihat ke bagian dropdown pilih kelompok, ditandai dengan warna merah, sedangkan untuk dropdown pilih daerah dan button 'pilih' berwarna biru muda menuju kuning yang artinya tidak terlalu sering dilihat oleh reponden.

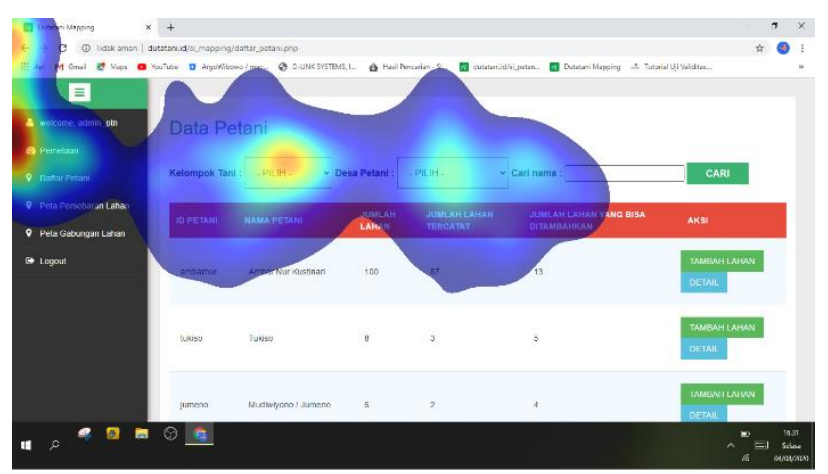

Gambar 15. Heatmap halaman daftar petani

Heatmap pada Gambar 15, menujukkan hasil heatmap pada task 3 [3]. Hasil menunjukkan bahwa responden secara otomatis melihat ke arah kiri untuk menemukan menu daftar 
petani. Sehingga responden akan lebih sering melihat kebagian tersebut sehingga fiksasi pada bagian tersebut semakin banyak dan menghasilkan warna merah.

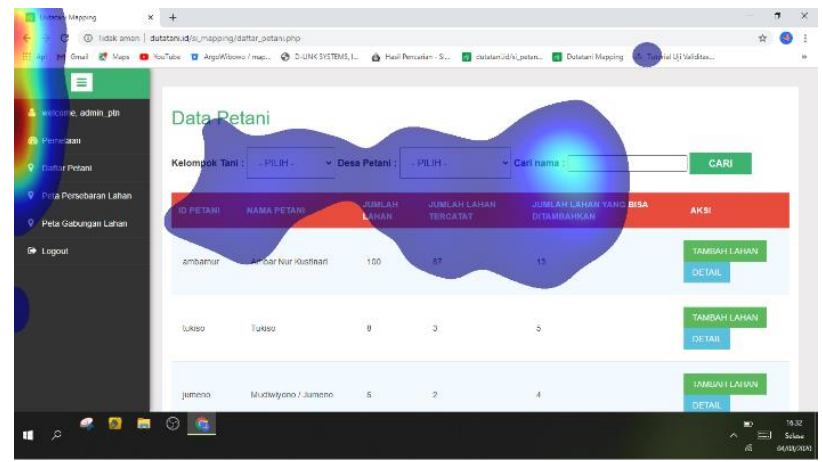

Gambar 16. Heatmap halaman daftar petani

Gambar 16 adalah hasil heatmap pada task 4 [3]. Hasil menunjukkan ketidaksesuaian dengan harapan penelitian terhadap fiksasi yang terjadi. Dimana penelitian ini mengharapkan responden lebih banyak melihat bagian cari nama dan button 'cari' pada area kanan halaman.

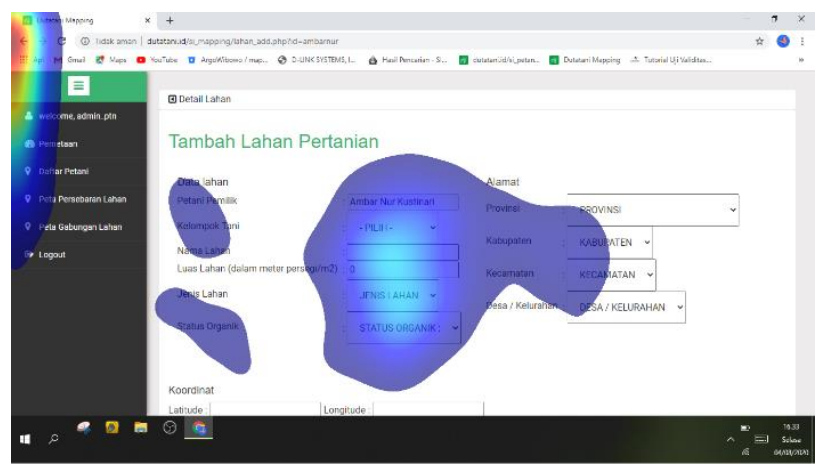

Gambar 17. Heatmap halaman tambah lahan

Gambar 17 diatas, adalah task untuk menambah lahan pertanian. Pada task tersebut responden cenderung melihat ke arah kiri atas, sedangkan yang diharapkan oleh penelitian ini adalah fiksasi terbesar terjadi pada bagian tengah halaman yaitu pada bagian inputan responden.

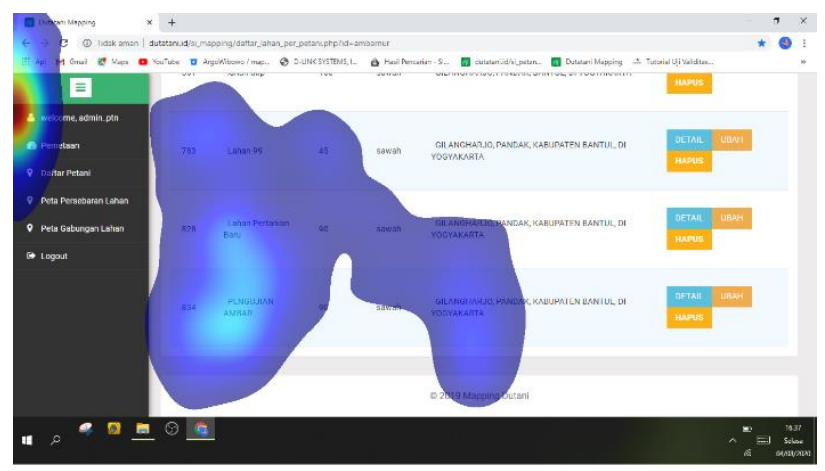

Gambar 18. Heatmap halaman daftar lahan petani

Berdasarkan hasil visualisasi heatmap pada Gambar 18, fiksasi terbanyak terjadi pada area menu yang ditandai dengan warna yang memerah, sedangkan pada bagian daftar lahan hanya berwarna biru, artinya responden tidak langsung melakukan scroll down pada halaman tersebut, namun responden mencoba untuk mencari daftar lahan petani pada bagian menu.

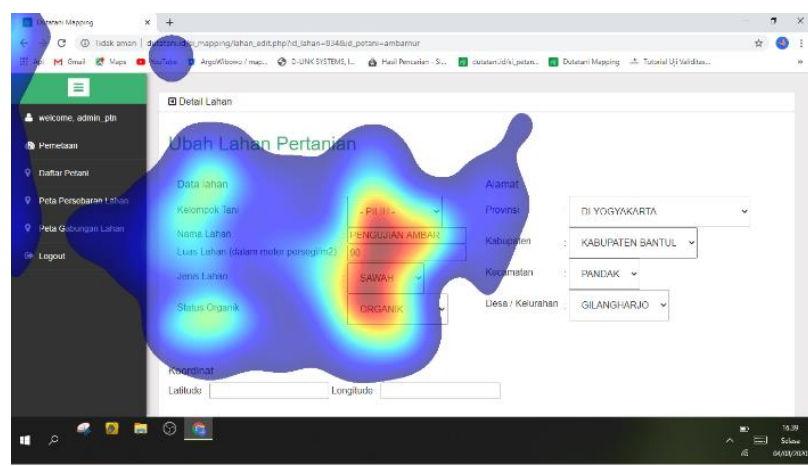

Gambar 19. Heatmap halaman ubah daftar lahan

Berdasarkan Gambar 19, hasil visualisasi heatmap sudah sesuai dengan harapan penelitian untuk melihat area penginputan data-data lahan. Hal itu ditunjukan dengan area yang berwarna merah.

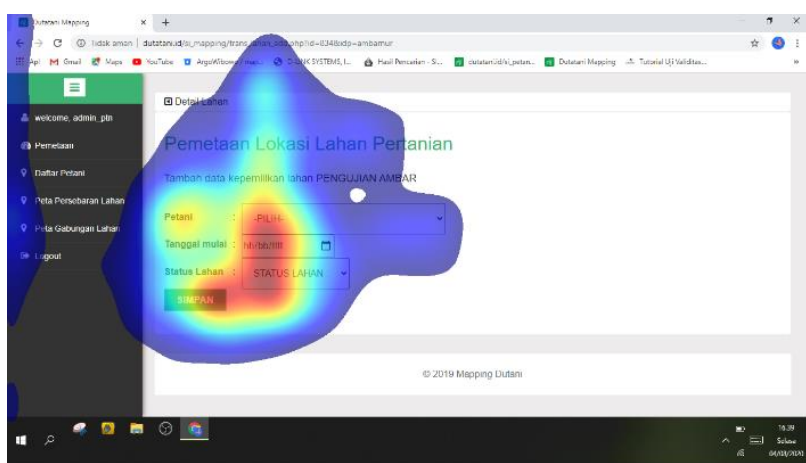

Gambar 20. Heatmap halaman tambah kepemilikan lahan

Gambar 20 diatas, adalah task untuk menambah kepemilikan lahan pertanian [3]. Pada bagian kolom kepemilikan lahan responden lebih sering melihat ke arah tengah halaman yang ditandai dengan fiksasi berwarna merah. Artinya responden banyak menghabiskan waktu untuk mengisi data-data yang akan diinputkan.

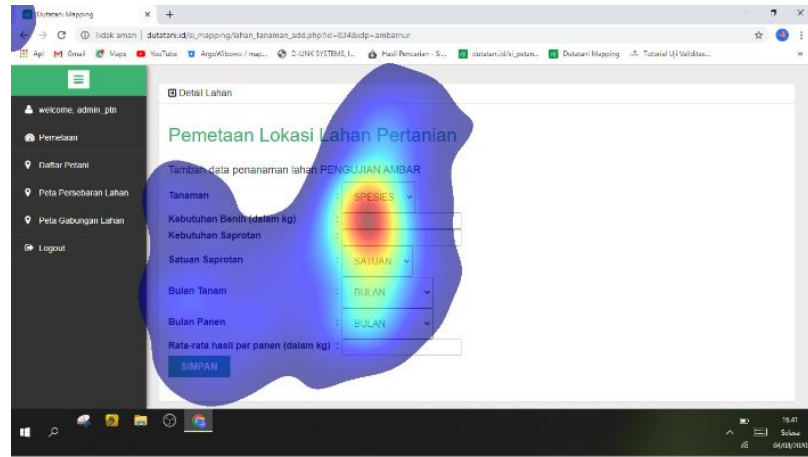

Gambar 21. Heatmap halaman tambah penanaman 
Pada Gambar 21 petani diminta untuk untuk menambahkan data penanaman pada petani. Berdasarkan hasil visualisasi, responden banyak melihat ke arah tengah halaman pada bagian kolom tambah data penanaman lahan pengujian ambar yang ditandai dengan fiksasi berwarna merah.

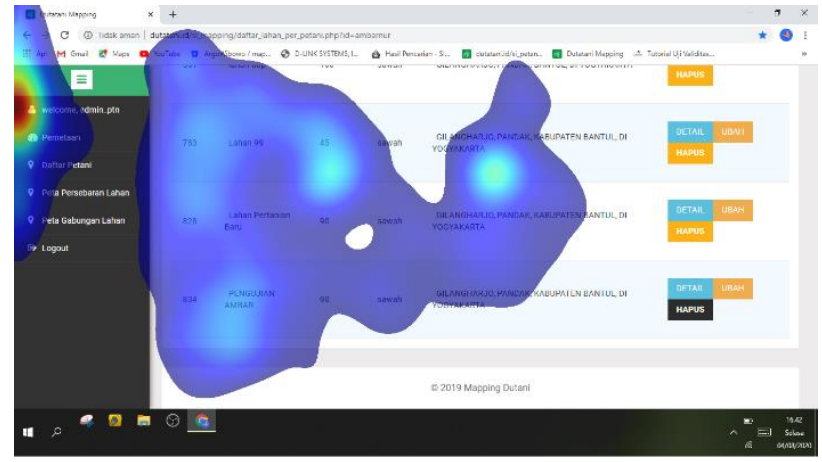

Gambar 22. Heatmap halaman daftar lahan

Pada task 10 responden diminta untuk menghapus lahan [3]. Berdasarkan hasil visualisasi pada Gambar 22, responden lebih sering melihat ke arah bagian kiri yang ditandai dengan area berwarna merah. Area berwarna biru di tengah halaman disebabkan oleh responden yang fokus untuk mencari lahan yang ingin dihapus dengan cara men-scroll. Namun, fiksasi yang terjadi tidak sebanyak pada saat responden mencari button hapus pada menu.

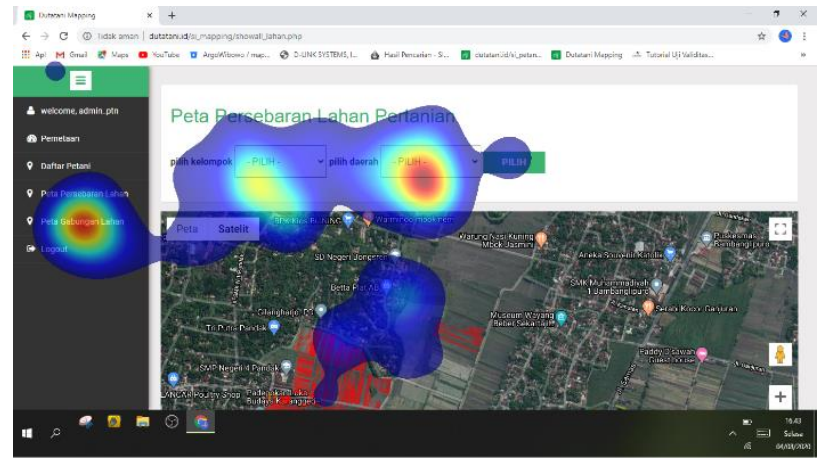

Gambar 23. Heatmap halaman peta pesebaran lahan

Secara umum visualisasi pada Gambar 23 yang dihasilkan sudah sesuai dengan harapan penelitian. Responden mengerjakan task dengan mencari menu peta persebaran lahan, namun titik fiksasi tidak seakurat yang diharapkan karena area berwarna merah ada pada menu peta gabungan lahan, bukan pada peta persebaran lahan.

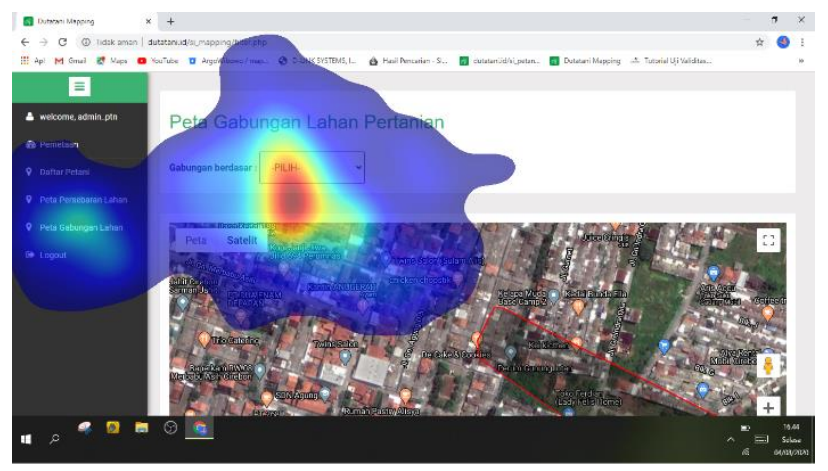

Gambar 24. Heatmap halaman peta gabungan lahan

Berdasarkan hasil visualisasi pada Gambar 24, responden lebih sering melihat kearah button gabungan berdasar yang ditandai dengan area berwarna merah. Pada bagian menu dan bagian tengah halaman juga terdapat warna biru yang menunjukkan bahwa responden juga melihat ke arah tersebut namun tidak sesering pada bagian button gabungan berdasar.

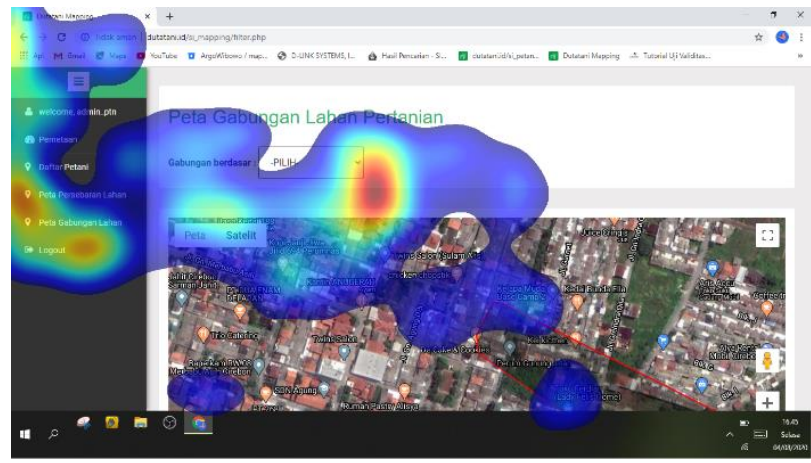

Gambar 25. Heatmap halaman logout

Berdasarkan Gambar 25, responden juga cukup sering melihat ke arah bagian kiri halaman yang ditandai dengan warna kuning kecoklatan pada menu. Termasuk juga pada pilihan logout namun memang tidak sesering pada bagian tengah halaman. Responden juga beberapa kali mengeksplor ke beberapa bagian halaman untuk mencari menu yang dituju yang ditandai dengan area berwarna biru.

Berdasarkan hasil visualisasi heatmap dari masing masing task di atas, dapat dikelompokkan menjadi dua berdasarkan bagian yang sudah sesuai dengan harapan penelitian dan yang tidak sesuai. Visualisasi heatmap dapat dikatakan sesuai jika area yang dimaksud oleh penelitian ini menampilkan fiksasi terbanyak yang ditandai dengan warna yang semakin merah. Dari 13 task yang diujikan terdapat 9 task yang sudah sesuai dengan harapan penelitian, sedangkan 4 lainnya tidak. Heatmap yang tidak sesuai bisa terjadi karena banyak faktor seperti gagal fokusnya responden pada saat pengujian karena ter-distract oleh lingkungan sehingga arah pandang mata responden tidak akurat. Oleh karena itu dapat diberikan saran jika penelitian dengan menggunakan teknologi eye tracker diharapkan untuk memperhatikan kondisi lingkungan agar responden tidak gagal fokus dalam 
menyelesaikan tugas. Hasil heatmap dikategorikan seperti Tabel II.

TABEL II

KATEGORI HASIL VISUALISASI HEATMAP

\begin{tabular}{|c|c|}
\hline Heatmap yang tepat & Heatmap yang tidak tepat \\
\hline $\begin{array}{ll}\text { - } & \text { Task } 1: \text { Login } \\
\text { - } & \text { Task } 2: \text { Memilih pemetaan } \\
& \text { lokasi } \\
\text { - } & \text { Task } 3: \text { Melihat daftar } \\
& \text { petani } \\
\text { - } & \text { Task } 7: \text { Mengubah data } \\
& \text { lahan petani } \\
\text { - } & \text { Task } 8: \text { Menambah } \\
& \text { kepemilikan lahan } \\
\text { - } & \text { Task } 9: \text { Menambah } \\
\text { penanaman } \\
\text { Task } 11: \text { Melihat peta } \\
\text { pesebaran lahan } \\
\text { Task } 12: \text { Melihat peta } \\
\text { gabungan lahan } \\
\text { Task } 13: \text { Logout }\end{array}$ & $\begin{array}{ll}\text { - } & \text { Task 4: Mencari nama } \\
& \text { petani } \\
\text { - } & \text { Task 5: Menambah } \\
& \text { lahan petani } \\
\text { - } & \text { Task 6: Melihat lahan } \\
& \text { petani } \\
\text { - } & \text { Task 10: Menghapus } \\
& \text { lahan pertanian }\end{array}$ \\
\hline
\end{tabular}

\section{Hasil Pengujian Penerimaan}

1) Evaluasi Hasil Pengukuran (Outer Model): Hasil pengukuran seperti Gambar 26 dibawah ini.

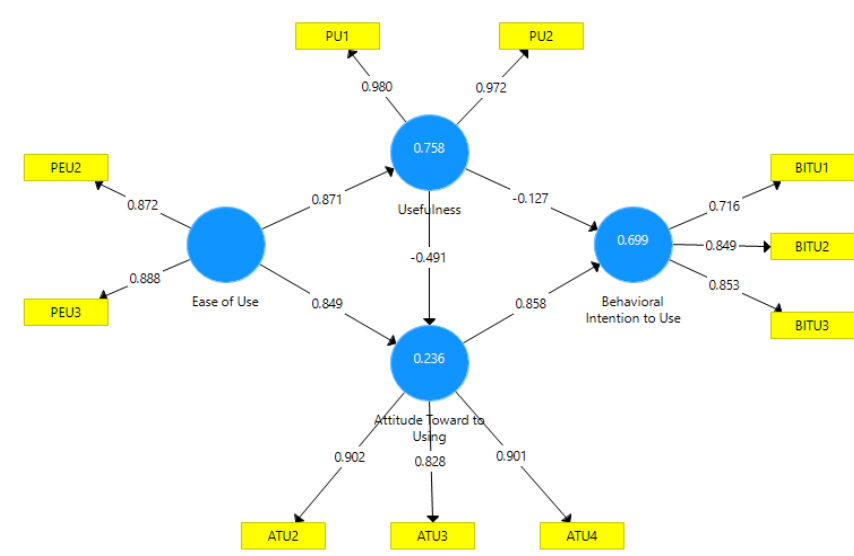

Gambar 26. Hasil Outer Model

Convergent validity diukur dengan melihat nilai Average Variance Extracted (AVE). Berdasarkan Tabel III dibawah ini, korelasi antar indikator suatu variabel sudah dikatakan baik karena menunjukkan nilai diatas standar minimum yaitu 0,5 . Dengan demikian keempat variabel sudah memenuhi kriteria convergent validity.

TABEL III

NILAI AVE

\begin{tabular}{|c|c|}
\hline & AVE \\
\hline ATU & 0,771 \\
\hline BITU & 0,654 \\
\hline PEU & 0,775 \\
\hline PU & 0,953 \\
\hline
\end{tabular}

Selain itu outer model dapat diketahui dari nilai cross loading yang merupakan nilai korelasi setiap indikator terhadap variabel latennya cukup tinggi dibandingkan dengan indikator variabel laten yang lain. Sehingga dapat disimpulkan bahwa validitas diskriminan dari masing masing variabel adalah valid. Nilai cross loading dapat dilihat pada Tabel IV.

TABEL IV

NILAI CROSS LOADING

\begin{tabular}{|c|c|c|c|c|}
\hline & ATU & BITU & PEU & PU \\
\hline ATU2 & 0,902 & 0,729 & 0,344 & 0,217 \\
\hline ATU3 & 0,828 & 0,702 & 0,427 & 0,117 \\
\hline ATU4 & 0,901 & 0,744 & $-0,022$ & 0,319 \\
\hline BITU1 & 0,450 & 0,716 & 0,400 & $-0,011$ \\
\hline BITU2 & 0,883 & 0,849 & 0,072 & 0,164 \\
\hline BITU3 & 0,543 & 0,853 & 0,872 & $-0,009$ \\
\hline PEU2 & 0,589 & 0,336 & 0,872 & 0,630 \\
\hline PEU3 & 0,167 & 0,106 & 0,888 & 0,895 \\
\hline PU1 & 0,279 & 0,125 & 0,900 & 0,980 \\
\hline PU2 & 0,200 & 0,038 & 0,792 & 0,972 \\
\hline
\end{tabular}

TABEL V

NILAI COMPOSITE RELIABILITY

\begin{tabular}{|c|c|}
\hline & COMPOSITE RELIABILITY \\
\hline ATU & 0,910 \\
\hline BITU & 0,849 \\
\hline PEU & 0,837 \\
\hline PU & 0,976 \\
\hline
\end{tabular}

Nilai composite reliability disimpulkan bahwa semua indikator dianggap mampu mengukur setiap variabel latennya. Dan dapat dikatakan bahwa keempat variabel diatas telah reliabel karena nilai composite reliability $>0,7$. Nilai composite reliability dapat dilihat pada Tabel V.

2) Evaluasi Hasil Struktural (Inner Model): Pengukuran evaluasi model struktural atau inner model dilihat dari hubungan antar variabel laten yang akan diukur dengan nilai koefisien determinasi dan nilai koefisien jalur seperti Tabel VI dibawah ini.

TABEL VI

NILAI R-SQUARE

\begin{tabular}{|c|c|}
\hline & R-SQUARE \\
\hline PEU & - \\
\hline ATU & 0,849 \\
\hline BITU & 0,837 \\
\hline PU & 0,976 \\
\hline
\end{tabular}


Pengujian tingkat signifikansi sebuah nilai koefisien jalur dapat dilakukan dengan metode bootstrapping pada software SmartPLS versi 3. Dari metode bootstrapping diperoleh nilai $\mathrm{t}$ ( $t$-Statistic) dan probabilitas dari semua koefisien jalur yang diajukan pada hipotesis. Nilai t ( $t$-Statistic) yang diperoleh akan dibandingkan dengan nilai T-tabel. Hasil koefisien determinasi disajikan dalam bentuk Tabel VII.

TABEL VII

KOEFISIEN DETERMINASI

\begin{tabular}{|c|c|c|c|}
\hline \multicolumn{2}{|c|}{ Hipotesis } & $\begin{array}{c}\text { Original } \\
\text { Sample }(\boldsymbol{\beta})\end{array}$ & $\begin{array}{c}\text { T-Statistik } \\
(\mathrm{t} \text { hitung })\end{array}$ \\
\hline H1 & PEU $\rightarrow$ PU & $\mathbf{0 , 8 7 1}$ & 13,792 \\
\hline H2 & PEU $\rightarrow$ ATU & 0,849 & 1,375 \\
\hline H3 & PU $\rightarrow$ ATU & $-0,491$ & 0,512 \\
\hline H4 & PU $\rightarrow$ BITU & $-0,127$ & 0,300 \\
\hline H5 & ATU $\rightarrow$ BITU & 0,858 & 1,985 \\
\hline
\end{tabular}

\section{E. Uji Hipotesis}

Pengujian hipotesis menggunakan statistik uji yang disebut sebagai statistik t. Dalam penelitian ini, nilai $t$ pembanding didapat berdasar tabel $\mathrm{t}$ yaitu pada derajat kebebasan, dimana jumlah responden - jumlah variabel. Tingkat keyakinan yang digunakan adalah $95 \%$ atau a $=5 \%$. Dalam penelitian ini, sampel sebanyak 20 sedangkan variabel 4, maka derajat kebebasan atau degree of freedom (df) yang digunakan adalah 16, maka nilai tabel t yang digunakan adalah 1,746 pada sebagai pembanding. Apabila T statistik > 1,764 maka hipotesis berpengaruh positif, sebaliknya jika $\mathrm{T}$ statistik < 1,764 maka hipotesis berpengaruh negatif. Hasil koefisien determinasi dapat dilihat pada Tabel VIII.

TABEL VIII

KOEFISIEN DETERMINASI

\begin{tabular}{|c|c|c|c|c|c|c|}
\hline \multicolumn{2}{|c|}{ Hipotesis } & $\begin{array}{c}\text { Original } \\
\text { Sample }\end{array}$ & $\begin{array}{c}\text { T- } \\
\text { Statisti } \\
\text { k (t } \\
\text { hitung) }\end{array}$ & $\begin{array}{c}\text { T- } \\
\text { tabel }\end{array}$ & $\begin{array}{c}\text { P- } \\
\text { Value } \\
\text { s }\end{array}$ & Hasil \\
\hline H1 & $\begin{array}{c}\text { PEU } \rightarrow \\
\text { PU }\end{array}$ & $\mathbf{0 , 8 7 1}$ & $\mathbf{1 3 , 7 9 2}$ & 1,746 & 0,000 & $\begin{array}{c}\text { Diterim } \\
\text { a }\end{array}$ \\
\hline H2 & $\begin{array}{c}\text { PEU } \rightarrow \\
\text { ATU }\end{array}$ & 0,849 & 1,375 & 1,746 & 0,170 & Ditolak \\
\hline H3 & $\begin{array}{c}\text { PU } \rightarrow \\
\text { ATU }\end{array}$ & $-0,491$ & $\mathbf{0 , 5 1 2}$ & 1,746 & 0,609 & Ditolak \\
\hline H4 & $\begin{array}{c}\text { PU } \rightarrow \\
\text { BITU }\end{array}$ & $-\mathbf{0 , 1 2 7}$ & $\mathbf{0 , 3 0 0}$ & 1,746 & 0,764 & Ditolak \\
\hline H5 & $\begin{array}{c}\text { ATU } \rightarrow \\
\text { BITU }\end{array}$ & $\mathbf{0 , 8 5 8}$ & 1,985 & 1,746 & 0,048 & $\begin{array}{c}\text { Diterim } \\
\text { a }\end{array}$ \\
\hline
\end{tabular}

1) PEU terhadap PU: Jalur koefisien PEU (persepsi kemudahan) terhadap PU (persepsi kegunaan) dapat diterima, hal ini dibuktikan dari besarnya nilai $t$ statistik untuk konstruk PEU terhadap konstruk PU di atas 1,764 yaitu sebesar 13,792 .

2) $\quad P E U$ terhadap ATU: Jalur Jalur koefisien PEU (persepsi kemudahan) terhadap ATU (persepsi sikap penggunaan) ditolak. Hal tersebut ditunjukkan dari nilai t statistik untuk variabel kemudahan terhadap variabel sikap penggunaan memiliki nilai dibawah t tabel 1,764 yaitu 1,375.untuk konstruk PEU terhadap konstruk PU di atas 1,764 yaitu sebesar 13,792 .

3) $\quad P U$ terhadap ATU: Jalur koefisien PU (persepsi kegunaan) terhadap ATU (persepsi sikap penggunaan) ditolak. Hal tersebut ditunjukkan dari nilai t statistik untuk variabel kegunaan terhadap variabel sikap penggunaan memiliki nilai dibawah t tabel 1,764 yaitu 0,512 .

4) PU terhadap BITU: Jalur koefisien PU (persepsi kegunaan) terhadap BITU (persepsi minat penggunaan) ditolak. Hal tersebut ditunjukkan dari nilai t statistik untuk variabel kegunaan terhadap variabel minat penggunaan memiliki nilai dibawah $\mathrm{t}$ tabel 1,764 yaitu 0,300 .

5) ATU terhadap BITU: Jalur koefisien ATU (persepsi sikap penggunaan) terhadap BITU (persepsi minat penggunaan) dapat diterima, hal ini dibuktikan dari besarnya nilai t statistik untuk konstruk ATU terhadap konstruk BITU di atas 1,764 yaitu sebesar 1,985.

\section{SIMPULAN}

Berdasarkan hasil penelitian yang sudah dilakukan untuk pengujian usabilitas dan penerimaan aplikasi web mapping system lahan pertanian, diperoleh kesimpulan sebagai berikut:

1) Untuk pengujian usabilitas web mapping system, berdasarkan hasil combining metrics secara keseluruhan pengguna sudah baik dalam menyelesaikan task ditunjukkan oleh persentase task success sebesar 93\%, namun dalam menyelesaikan tugas tersebut, pengguna menghabiskan waktu cukup lama sehingga persentase time on task sebesar $43 \%$. Persentase error secara menyeluruh adalah $60 \%$, artinya masih banyak kesalahan yang dilakukan pengguna dalam menyelesaikan task yang diberikan, dan untuk jumlah klik sebesar $70 \%$ artinya tingkat efisien klik pengguna sudah cukup baik. Berdasarkan persentase tersebut maka perlu adanya perbaikan dari sisi sistem maupun sisi pengguna [3].

2) Pada pengujian penerimaan didapatkan hasil bahwa dari 5 hipotesis yang diajukan, hanya dua hipotesis yang diterima. Hipotesis yang diterima yaitu adanya pengaruh positif antara persepsi kemudahan (ease of use) terhadap persepsi kegunaan (usefulness) dan persepsi sikap penggunaan (attitude toward to using) terhadap persepsi minat perilaku penggunaan (behavioral intention to use) dan 
sisanya ditolak. Dari hasil tersebut dapat disimpulkan bahwa kemudahan penggunaan aplikasi web mapping system yang dirasakan pengguna dapat meningkatkan persepsi pengguna tentang kebergunaan aplikasi web mapping system tersebut untuk meningkatkan efektivitas pekerjaan mereka. Selain itu sikap pengguna yang termotivasi dalam menggunakan sistem juga dapat meningkatkan niat mereka untuk rutin menggunakan sistem dikemudian hari secara terus menerus guna menunjang kegiatan mereka dalam bidang pertanian.

\section{UCAPAN TERIMA KASIH}

Dalam penelitian ini, penulis mengucapkan terima kasih kepada Kemenristek DIKTI melalui hibah PTUPT 2020, LPPM UKDW, dan Fakultas Teknologi Informasi UKDW Yogyakarta atas semua bantuan dan dukungannya dalam penelitian ini.

\section{DAFTAR PUSTAKA}

[1] A. . R. Chrismanto, R. Delima, H. . B. Santoso, A. Wibowo and R. . A. Kristiawan, "Developing Agriculture Land Mapping using Rapid Application Development (RAD): A Case Study from Indonesia," (IJACSA) International Journal of Advanced Computer Science and Applications, pp. Vol. 10, No. 10, 2019.

[2] J. S. Dumas and J. C. Redish, A Practical Guide to Usability Testing, Intellect, 1999.

[3] A. R. Chrismanto, J. Purwadi, A. Wibowo, H. B. Santoso, R. Delima and D. Balisa, "Perbandingan Pengujian Fungsional dan Usabilitas Sistem Pemetaan Lahan Pertanian Pada Platform Web dan Mobile," SEMNASTIK APTIKOM, 2020.

[4] C. A. Mango, "Pembuatan Sistem Informasi Geografis Peta Bidang Tanah Berbasis Web Mapping," 2019.

[5] A. P. R. Pinem, "Web-Based Mapping Untuk Pemetaan Lokasi Kerusakan Jalan Raya Menggunakan Cluster Marker," SISFOKOM, p. 02, 2018.

[6] A. Wibowo, H. B. Santoso, A. R. Chrismanto and R. Delima, "Mapping and Grouping of Farm Land with Graham Scan Algorithm on Convex Hull Method," IEEE, 2019.
[7] R. Karnita and D. Meiralarasari, "Metode Visual Interpretatif Terhadap Tampilan,” J@TI Undip, pp. Vol V, No 1, 2010.

[8] J. Ross, "Eyetracking: Is It Worth It?," Di-unduh dari https://www.uxmatters.com/mt/archives/2009/10/eyetracking-isit-worth-it.php, 2009.

[9] F. D. Davis, R. p. Bagozzi and P. R. Warshaw, "User Acceptance Of Computer Technology: A Computer Of Two Theoritical Models," Management Science, p. 982, 1989.

[10] A. R. Chrismanto, H. B. Santoso, A. Wibowo and R. Delima, "Studi Kelayakan Penerapan Web Mapping System Menggunakan Metode Telos," SEMINAR NASIONAL Dinamika Informatika 2020 Universitas PGRI Yogyakarta, 2020.

[11] H. B. Santoso, A. Wibowo, R. Delima, A. Rachmat and R. Ariel "Analisis Kebutuhan dan Stakeholder Mapping Untuk Web Mapping System Lahan Pertanian di Gilangharjo, Bantul," PROSIDING KONSER KARYA ILMIAH NASIONAL 2019, pp. ISSN 2460-5506, 2019.

[12] T. Tullis and B. Albert, "Measuring the User Experience Collecting, Analyzing, and Presenting Usability Metrics," Elsivier Inc, 2013.

[13] N. J. Salkind, Exploring Research, 2012.

[14] P. I. Santosa, Metode Penelitian Kuantitatif Pengembangan Hipotesis dan Pengujiannya Menggunakan SmartPLS, Yogyakarta: Penerbit ANDI, 2018

[15] Y. Herawati, S. Halim and C. Tesavrita, Evaluasi Website Rakuten Indonesia dengan Eyetracking Usability Testing, 2015.

[16] F. and M. Ariandi, "Penerapan Metode Technology Acceptance Model (TAM) Terhadap Penerimaan KRS Online," Jurnal Ilmiah MATRIK, pp. 1-20, 2008.

[17] A. Tuca and J. Asrani, "NewsCard," 2019. [Online]. Available: https://justfreethemes.com/.

[18] U. Agustina and M. Arief, "Pengaruh Persepsi Manfaat dan Persepsi Kemudahan Terhadap Sikap Penggunaan Layanan Internet Banking (Studi Pada Komunitas Virtual E-Banking BCA)," Jurnal Ekonomi Bisnis Tahun 20, pp. 53-138, 2015.

[19] M. Alexandrou, "RSS Include Pages," 2019. [Online]. Available: https://wordpress.org/plugins/rss-includes-pages/. 